\title{
Effect of umbel position on dill (Anethum graveolens L.) plants growing in field stands on selected seed stalk features
}

\author{
Roman Holubowicz', Maria Morozowska ${ }^{2}$ \\ ${ }^{1}$ Department of Seed Science and Technology \\ Poznań University of Life Sciences \\ Szamotulska 28, 62-081 Przeźmierowo, Poland \\ ${ }^{2}$ Departemnt of Botany \\ Poznań University of Life Sciences \\ Wojska Polskiego 71C, 60-625 Poznań, Poland \\ e-mail: rhseed@up.poznan.pl
}

\begin{abstract}
Research was carried out on the effect of the umbel position on the 'Amat' dill (Anethum graveolens L.) plant on selected features of the seed stalk in the years 2002-2004. Commercial seeds of the species were sown on a small production field and grown for the purpose of producing seeds. Out of the field plant stands, three hundred plants were randomly selected. The following morphological features were then measured in respect to the seed stalk architecture in these plants: the length of the seed stalk, number of branches with primary, secondary and tertiary umbels, length of branches with primary umbels, as well as the main and primary umbel diameters. In addition, seed yield per plant, the weight of 1000 seeds, germination capacity, seed length and width, seed embryo and endosperm lengths for seeds from the main and primary umbels were also calculated and measured. Additionally, the main and primary umbels were divided into three parts: external, middle and internal, and seeds from each were examined separately. The position of the umbel on the seed stalk did not affect the number of branches with primary, secondary, and tertiary umbels on the dill plant and had no effect on its seed stalk architecture. There was no significant difference within the position of the main and primary umbels on the seed stalk grown in field stands. The diameter of the main umbel was the same as the primary one. The lower its position on the seed stalk, the lower the seed yield and germination capacity. The best seeds, in terms of their 1000 seed weight, came from the external part of the main umbel. The different localisation of seeds within the three designated parts of the main umbel had no effect on seed length or width or on their endosperm and embryo lengths. The recorded seed embryo length from the internal part of the primary umbel was smaller than its values from the two other parts of that umbel.
\end{abstract}

Key words: 1000 seed weight, seed stalk architecture, seed germination, seed structure

\section{INTRODUCTION}

Dill (Anethum graveolens L.) is a well-known vegetable and medicinal plant grown in many countries all over the world (Kaufman and Pölitz 1990, Kaur and Arora 2010). In Poland, it is commonly used for flavouring cucumbers when souring. The species belongs to the Apiaceae family. Plants from this family are characterised by gradually blooming and maturing umbels, whose position on seed stalks reportedly affects seeds germination (Lityński 1977, Gray 1979, George 1985, Woyke and Łazęcka 1993, Szafirowska 1994, Kelly and George 1998, Muhammad and Anjum 2001, Pereira et al. 2008, Panayotov 2010). However, only a few dill cultivars have been developed by seed companies and therefore there is significantly little research concerning seed production, though there is an annual market demand for seeds used 
for seed production (Korohoda 1974). On the other hand, there have been reports about problems with producing high quality seeds (McDonald and Copeland 1997), including this species. A few factors have been proven to affect the final dill seed quality, such as the quality of the seeds used for sowing, weather conditions, soil cultivation and proper disease and pest control (Woyke 1989, Komorowska and Sokołowska 1990, Sokołowska et al. 1994, Woyke and Lazęcka 1994, Szopińska and Bralewski 2006).

When reading the results of the previous experiments done with the species, the question remains: to what extent are those studies, conducted either in the laboratory or on small, experimental plots, adequate for real commercial field production conditions? Would these results be the same if only the commercially important characteristics of dill field stand seed stalks were taken? Could the location of the seeds in the main and primary umbels affect the morphology and sowing value of the seeds? Could some elements of the dill seed structure affect their quality? These were the main goals of the experiments that were carried out.

\section{MATERIAL AND METHODS}

The materials for this experiment were 'Amat' commercial garden dill (Anethum graveolens L.) seeds from Spójnia, a horticultural plant breeding and seed production limited liability company located in Nochowo, near Poznań (Western Poland). The cultivar is a Polish breeding selection and has been commonly grown by professional gardeners in Poland. It has a straight, compact growth tendency and a strong aroma suitable for souring cucumbers. It is a medium early, high yielding cultivar.

The research was carried out in the years 20022004 at the Baranowo Agricultural Experiment Station belonging to the Poznań University of Life Sciences. The field used had podzolic soils created from clay sands and located on a light clay with a humus level of $0.9-1.0 \%$. In the previous years, sweet pea (2002), common bean (2003) and cereals (2004) had been grown on the field used for the research. The experiment began by establishing

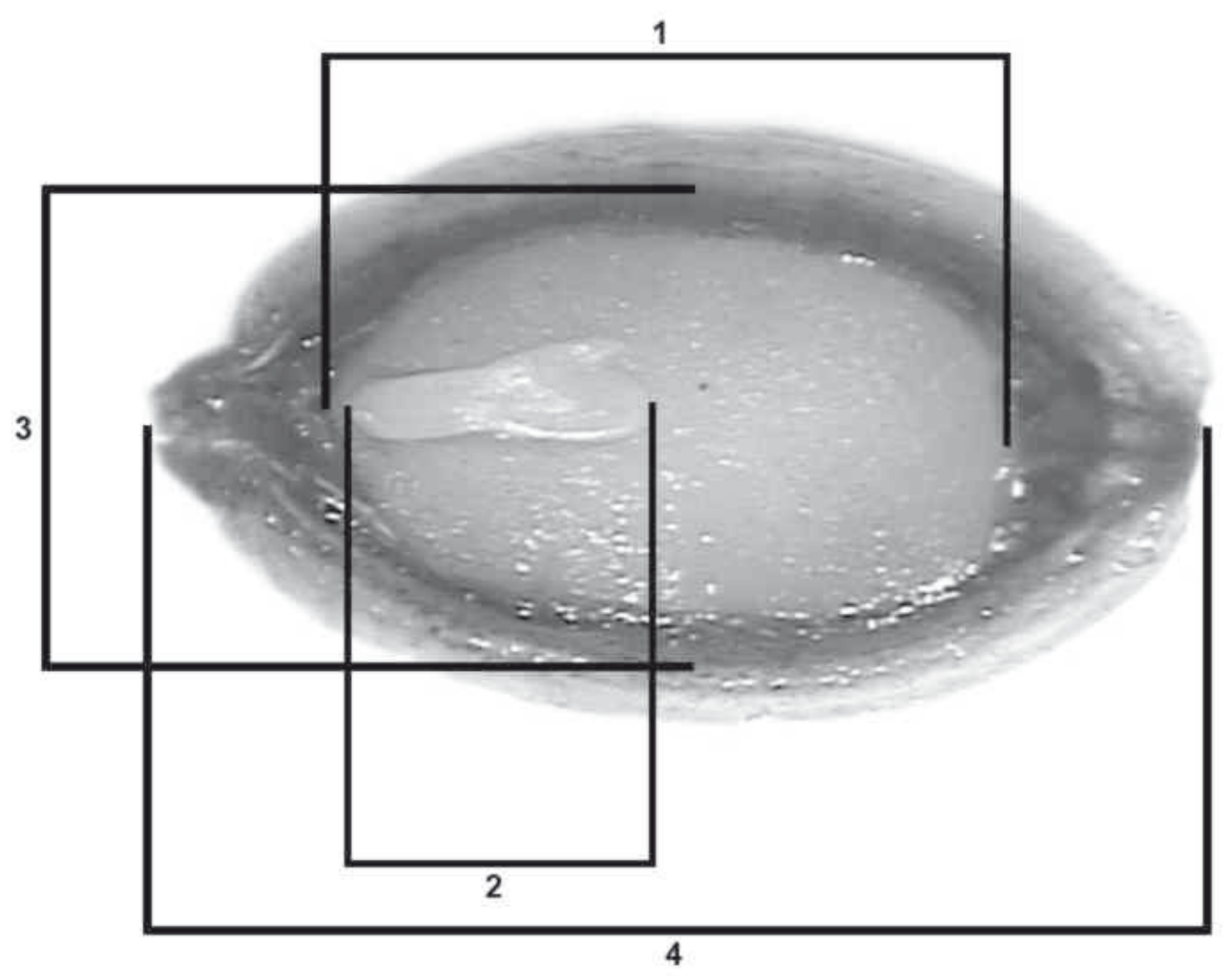

Figure 1. Longitudinal section of dill seed showing its length (4) and width (3) as well as the methods of measuring embryo (2) and endosperm (1) lengths 


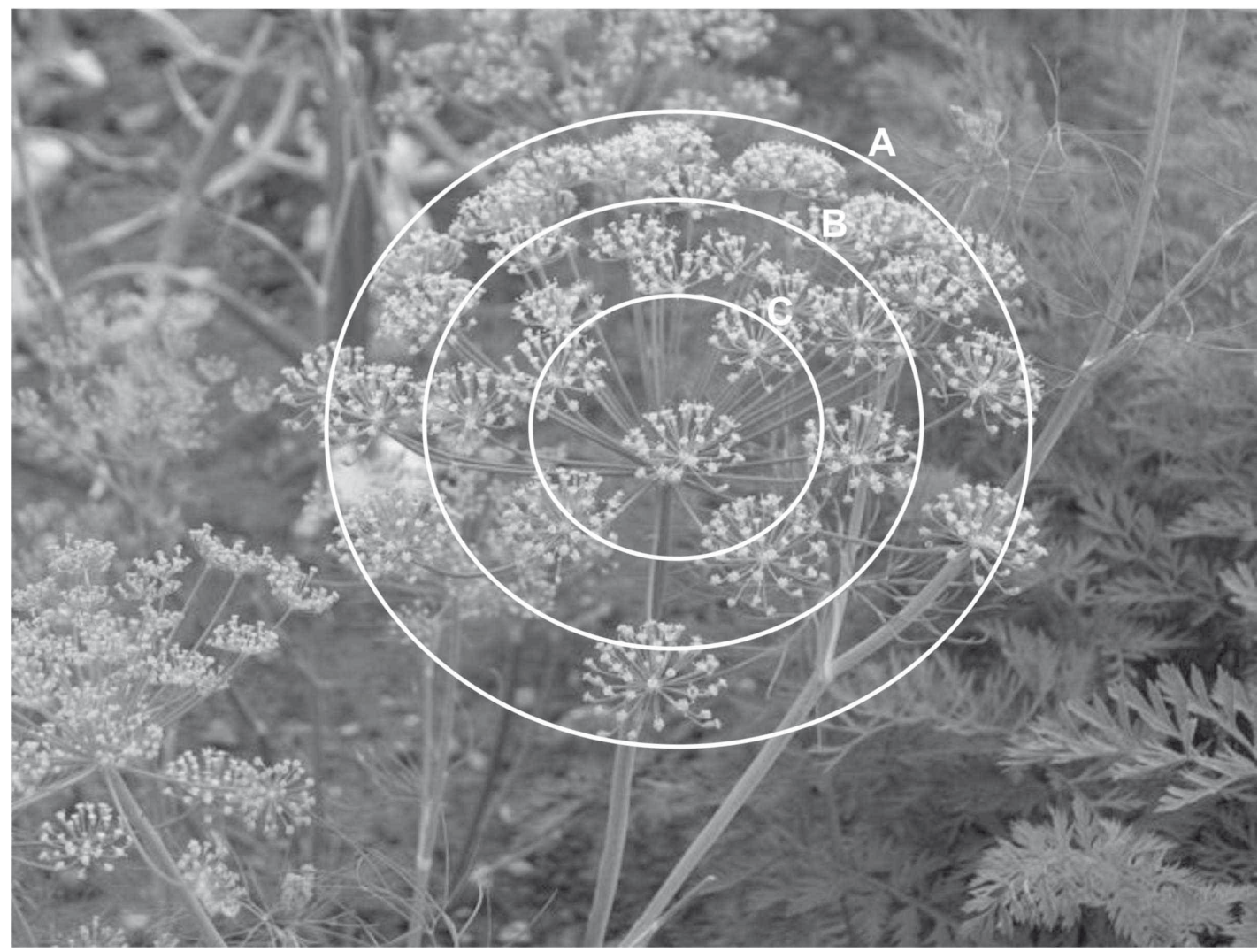

Figure 2. The main dill umbel with its three designated parts: external (A), middle (B) and internal (C)

a small $(30 \mathrm{~m} \times 50 \mathrm{~m})$ production field of dill routinely grown with the purpose of producing seeds using standard fertilisation, selection and plant control. The seeds were sown by hand in a spacing of $50 \mathrm{~cm}$ by $20 \mathrm{~cm}$. Three hundred plants, growing at least $5 \mathrm{~m}$ from the edge of the field, were randomly selected out of the field stand.

In all of these 300 plants, the following morphological features were measured in respect to the seed stalk architecture: the length of the seed stalk, number of branches with primary, secondary and tertiary umbels, length of branches with primary umbels, height of the primary branch outgrowth on the seed stalk as well as the main and primary umbel diameters. In addition, seed yield per plant, 1000 seed weight, germination capacity at the first and final count, seed length and width, seed embryo and endosperm lengths for seeds from the main and primary umbels were also calculated and measured (Fig. 1). Additionally, the main and primary umbels were divided into three parts: external, middle and internal (Fig. 2), and seeds from each were examined separately. All measurements concerning seed yield were taken in three replications of 100 plants selected as every third plant from the 300 plants grown in the field stand. For the seed structure measurements, three replications of 30 seeds were randomly taken from the plants. Seed quality was examined after the post-harvest drying, four weeks after the harvest. The seeds were then tested for germination capacity with the use of the routine method accepted by the International Seed Testing Association (ISTA 1999).

The collected data were used to carry out a single factor variance analysis. The significant differences were calculated using the Duncan test at a significance level $\alpha=0.05$.

\section{RESULTS AND DISCUSSION}

The weather conditions during the duration of the experiment should be considered as medium good or good in terms of dill seed production. The year 2002 was a medium good one. At first, a long winter delayed seed sowing. Then, a draught in May further delayed the vegetation of the seedlings. However, later on, in the second half of the month, it improved significantly (it was warm and rainy) and the plants soon caught up with the vegetation. Still, high levels of precipitation and storms with heavy winds in the blooming period led to poor bee populations, which resulted in a lower than normal seed set. The year 2003 should be considered a good one in regards to this aspect. At first, it looked like a bad year due to a draught at the end of April and the beginning 
of May, which seriously delayed plant vegetation. In addition, strong rains at the beginning of July weakened the seed set. However, in the middle of July, the weather significantly improved and rains at the end of July helped in the good setting and growth of the seeds, which resulted in good seed yield per plant. In turn, dry weather at the end of August resulted in good drying of the seeds on the plants. A lack of strong winds on the field at harvest time additionally lowered seed losses due to their scattering from umbels. The year 2004 was medium good for dill seed production. Although cold weather in June significantly delayed the vegetation of plants, good sunny weather during blooming time and a lack of strong winds just before harvest positively affected the final seed yield.

A big advantage of the present research was that the analysed data was obtained from observations carried out on a large number of plants grown in field stands. Moreover, the given data refers to three consecutive years of the experiment, in which various weather conditions were recorded during seed production. The weather has been proven to be a top factor in successful seed production of dill and other vegetables (Woyke 1989, Kawecka and Dyduch 2006).

The research that was carried out showed that according to the umbel position on the seed stalk, the average number of branches with primary, secondary, and tertiary umbels per dill plant did not differ and had no effect on the seed stalk architecture. The mean value of the length of branches with primary umbels $(40.4 \mathrm{~cm})$ combined with the average height of their outgrowth on the seed stalk $(42.3 \mathrm{~cm})$ showed no difference compared to the length of the seed stalks carrying the main umbel (Tab. 1). There was no significant difference within the position of the main and primary umbels on the dill plants grown in field stands. This is in agreement with other experiments done by Callan et al. (2007), who found out that changes in the seed stalk architecture, through different plant density in the field, had no effect on the final green mass production and oil quality. In addition, Woyke and Łazęcka (1994) confirmed that since dill flowers and seeds gradually bloom and ripen in umbels, like other plants from the Apiaceae family, the stage of harvest has a crucial effect on their quality.

The obtained results show that the average umbel diameter did not depend on the position of the umbel on the seed stalk. However, the average diameter of the main umbel was a few centimetres larger compared to the primary one (Tab. 1). Still, the high variability of measurements (from $12.4 \mathrm{~cm}$ to $22.9 \mathrm{~cm}$ and from 8.2 to $12.2 \mathrm{~cm}$ for the main and primary umbels, respectively) made it impossible to prove that this feature was significantly different. Perhaps it came from a genetically less stable cultivar, as reportedly there were no cultivars but only selected types and clones in dill breeding over 30 years ago (Korohoda 1974).

The position of the umbel on the dill seed stalk had a significant effect on some of its morphological features (Tab. 1). There was a clear difference in the seed yield per plant related to the position of the umbel on the dill seed stalk. The lower its position on the seed stalk, the lower the seed yield. The best seeds, in terms of their 1000 seed weight, were collected from the main umbel. Thousand seed weights from the primary and secondary umbels were the same.

The positive effect of umbel position on seed yield through plant density in the field that we recorded confirmed the results obtained earlier by Randhava et al. (1987), Kaufmann and Pőltz (1990) and Woyke and Łazęcka (1994). The same refers to 1000 seed weight as well as their quality. The crucial role of seed weight in dill seed germination and field emergences was confirmed by Komorowska and Sokołowska (1990) and Sokołowska et al. (1994).

The position of the umbel on the dill seed stalk also affected the germination capacity of its seeds (Tab. 1). The lower the position of the umbel, the lower the seed germination capacity. The average value of germination capacity at the first count for seeds from the main umbel was $61.7 \%$, whereas

Table 1. Effect of umbel position on the dill seed stalk on its selected features

\begin{tabular}{|c|c|c|c|c|c|c|c|}
\hline \multirow{2}{*}{$\begin{array}{l}\text { Umbel } \\
\text { position }\end{array}$} & \multirow{2}{*}{$\begin{array}{c}\text { Number of } \\
\text { branches }\end{array}$} & \multirow{2}{*}{$\begin{array}{l}\text { Height of the } \\
\text { umbel localisation } \\
\text { on the plant }(\mathrm{cm})\end{array}$} & \multirow{2}{*}{$\begin{array}{l}\text { Umbel } \\
\text { diameter } \\
(\mathrm{cm})\end{array}$} & \multirow{2}{*}{$\begin{array}{l}\text { Seed yield } \\
\text { (g plant) }\end{array}$} & \multirow{2}{*}{$\begin{array}{c}1000 \text { seed } \\
\text { weight } \\
(\mathrm{g})\end{array}$} & \multicolumn{2}{|c|}{ Germination capacity (\%) } \\
\hline & & & & & & First count & Final count \\
\hline Main & - & $78.3 \mathrm{a}$ & $17.2 \mathrm{a}$ & $1.9 \mathrm{~d}$ & $1.8 \mathrm{~b}$ & $61.7 \mathrm{c}$ & $62.7 \mathrm{c}$ \\
\hline Primary & $4.8 \mathrm{a}^{*}$ & $82.7 \mathrm{a}$ & $10.6 \mathrm{a}$ & $0.7 \mathrm{c}$ & $1.4 \mathrm{a}$ & $29.3 \mathrm{~b}$ & $30.6 \mathrm{~b}$ \\
\hline Secondary & $6.2 \mathrm{a}$ & - & - & $0.3 \mathrm{~b}$ & $1.4 \mathrm{a}$ & $5.5 \mathrm{a}$ & $5.9 \mathrm{a}$ \\
\hline Tertiary & $5.4 \mathrm{a}$ & - & - & $0.1 \mathrm{a}$ & - & - & - \\
\hline
\end{tabular}

*Values marked with the same letter do not differ significantly at $\alpha=0.05$ 
it was $29.3 \%$ and $5.5 \%$ for the seeds from the primary and secondary umbels, respectively. At the final count, germination capacity had very similar results. The highest value, $62.7 \%$, was recorded for the seeds from the main umbel, whereas the seeds from the primary and secondary umbels germinated at $30.6 \%$ and $5.9 \%$, respectively.

The data we recorded also proved that the lower the position of an umbel on the seed stalk, the lower the seed yield, energy and germination capacity. This observation is true not only for dill plants but also for many species from the Apiaceae family (Korohoda 1974, Lityński 1977, Gray 1979, George 1985, Panayotov 2010). Szafirowska (1994), examining the correlation between mother plant architecture, seed quality and field emergence of carrot seeds, proved that the germinating capacity and the weight of 1000 seeds from primary umbels were higher than those of the remaining seeds. According to Corbineau et al. (1995), carrot seeds from primary and secondary umbels had higher percentages of germination capacity and developed larger seeds than those from the higher orders of umbels. The same results were found by Satyaveer et al. (1994) and Shantha et al. (1999).

Different seed localisation within the main umbel, according to its three designated parts, had a limited effect on the sowing value of the tested seeds (Tab. 2). Seeds from the external part had a higher 1000 seed weight than seeds from the other two parts. The part of the umbel where the examined seeds originated had no effect on their germination capacity, neither at the first nor at the final count. The variability of the sowing value fluctuated greatly for the seeds from the internal part of the umbel, but eventually the differences - more than $10 \%$ lower than for seeds from the external and middle parts - were not proven statistically, so they were considered insignificant. The obtained results cannot be compared to the results of other experiments done on dill due to there being no such results available in the literature, to the authors' best knowledge.

Different seed localisation within the three examined parts of the main umbel had no effect on selected features of their dill seeds (Tab. 3). The measured seed length varied from $4.21 \mathrm{~mm}$ to $3.77 \mathrm{~mm}$ but the recorded differences were not significant. Similarly, the seed width varied from 1.69 to $1.82 \mathrm{~mm}$, but the results were not significant. The same order was recorded for the seed embryo and endosperm length. Both these values varied from 1.12 to $1.25 \mathrm{~mm}$ and from 2.86 to $3.34 \mathrm{~mm}$, respectively, but they did not significantly differ from each other.

Different seeds localisation within the primary dill umbel, according to its three designated parts, had almost no effect on the selected structure parameters of its seeds (Tab. 4). Seed length varied from $3.39 \mathrm{~mm}$ for the internal part to $3.62 \mathrm{~mm}$ for the external part of the umbel. The recorded results, however, were not found to significantly differ. The same observation was recorded for the seed width. It varied from $1.57 \mathrm{~mm}$ for seeds from the internal part to $1.65 \mathrm{~mm}$ for seeds from the external part, but again all of these values were not significantly different. The recorded embryo length of the seeds from the internal part of the primary umbel was smaller than the values of this characteristic from the two other parts of the umbel. No such observation was made for the endosperm length. The average value of this characteristic varied from $1.94 \mathrm{~mm}$ to $3.07 \mathrm{~mm}$.

Table 2. Effect of seed localisation in the main umbel on the dill seed stalk on the sowing value of the seeds

\begin{tabular}{lccc}
\hline \multirow{2}{*}{$\begin{array}{l}\text { Part of the main } \\
\text { umbel }\end{array}$} & $\begin{array}{c}1000 \text { seed } \\
\text { weight } \\
(\mathrm{g})\end{array}$ & \multicolumn{2}{c}{$\begin{array}{c}\text { Germination } \\
\text { capacity }(\%)\end{array}$} \\
\cline { 3 - 4 } & & $\begin{array}{c}\text { first } \\
\text { count }\end{array}$ & $\begin{array}{c}\text { final } \\
\text { count }\end{array}$ \\
\hline $\begin{array}{l}\text { External } \\
\text { Middle }\end{array}$ & $1.8 \mathrm{~b}^{*}$ & $65.9 \mathrm{a}$ & $66.5 \mathrm{a}$ \\
Internal & $1.7 \mathrm{a}$ & $65.1 \mathrm{a}$ & $65.6 \mathrm{a}$ \\
& $1.7 \mathrm{a}$ & $54.2 \mathrm{a}$ & $55.2 \mathrm{a}$ \\
\hline
\end{tabular}

*Explanations: see Table 1

Table 3. Effect of seed localisation in the main umbel on the dill seed stalk on the selected seed structure parameters

\begin{tabular}{lcccc}
\hline $\begin{array}{l}\text { Part of } \\
\text { the main } \\
\text { umbel }\end{array}$ & $\begin{array}{c}\text { Seed } \\
\text { length } \\
(\mathrm{mm})\end{array}$ & $\begin{array}{c}\text { Seed } \\
\text { width } \\
(\mathrm{mm})\end{array}$ & $\begin{array}{c}\text { Embryo } \\
\text { length } \\
(\mathrm{mm})\end{array}$ & $\begin{array}{c}\text { Endosperm } \\
\text { length } \\
(\mathrm{mm})\end{array}$ \\
\hline External & $4.21 \mathrm{a}^{*}$ & $1.82 \mathrm{a}$ & $1.25 \mathrm{a}$ & $3.34 \mathrm{a}$ \\
Middle & $3.97 \mathrm{a}$ & $1.70 \mathrm{a}$ & $1.12 \mathrm{a}$ & $3.07 \mathrm{a}$ \\
Internal & $3.77 \mathrm{a}$ & $1.69 \mathrm{a}$ & $1.22 \mathrm{a}$ & $2.86 \mathrm{a}$ \\
\hline
\end{tabular}

*Explanations: see Table 1

Table 4. Effect of the seed localisation in the primary umbel on the dill seed stalk on the selected seed structure parameters

\begin{tabular}{lcccc}
\hline $\begin{array}{l}\text { Part of the } \\
\text { primary } \\
\text { umbel }\end{array}$ & $\begin{array}{c}\text { Seed } \\
\text { length } \\
(\mathrm{mm})\end{array}$ & $\begin{array}{c}\text { Seed } \\
\text { width } \\
(\mathrm{mm})\end{array}$ & $\begin{array}{c}\text { Embryo } \\
\text { length } \\
(\mathrm{mm})\end{array}$ & $\begin{array}{c}\text { Endosperm } \\
\text { length } \\
(\mathrm{mm})\end{array}$ \\
\hline $\begin{array}{l}\text { External } \\
\text { Middle }\end{array}$ & $3.62 \mathrm{a}^{*}$ & $1.65 \mathrm{a}$ & $1.22 \mathrm{~b}$ & $3.07 \mathrm{a}$ \\
Internal & $3.39 \mathrm{a}$ & $1.62 \mathrm{a}$ & $1.18 \mathrm{~b}$ & $2.99 \mathrm{a}$ \\
$1.97 \mathrm{a}$ & $1.13 \mathrm{a}$ & $1.94 \mathrm{a}$ \\
\hline
\end{tabular}

*Explanations: see Table 1 
The obtained results referring to the possible effect of seeds localisation in different parts of the main and primary dill umbels on the selected seed structure parameters cannot be compared to the results of any other studies done on this plant species or any other similar plant, as in the authors' best knowledge they are not available in the literature. However, Lityński (1977) summarised some earlier works done for carrot seed umbels divided into three parts and showed that the position of the individual small umbel in the umbel affected its final ripening time and, indirectly, the subsequently developed seed as well. The more interior the flower position in the umbel, the lower its embryo length. The observed differences disappeared within the following 60 days. One can only assume that since dill belongs to the same botanical family and the dill seeds used for the experiment were fully developed and typical for the species structure (Hołubowicz et al. 1992), a similar mechanism took place and thereby it was not possible to find any differences in the examined seeds structures.

\section{CONCLUSIONS}

1. The average number of branches with primary, secondary, and tertiary umbels per dill seed stalk did not differ and had no effect on the seed stalk architecture.

2. No significant differences were found for the position of the main and primary umbels on dill plants growing in field stands.

3. The average diameter of the main and primary umbels did not significantly differ.

4. The lower the position of the umbel on the seed stalk, the lower the seed yield and germination capacity. The best seeds, in terms of their 1000 seed weight, were collected from the external part of the main umbel.

5. Different localisation of seeds within the main umbel had no effect on seed length or width as well as on endosperm and embryo length.

6. The average embryo length of seeds from the internal part of the primary umbel was smaller than the same value of seeds from the two other parts of the umbel.

\section{ACKNOWLEDGEMENTS}

We would like to thank Ms Urszula Bak for her technical help in carrying out the experiments and her statistical analysis of the obtained data.

\section{REFERENCES}

Callan N.W., Johnson D.L., Westcott M.P., Welty L.E., 2007. Herb and oil composition of dill (Anethum graveolens L.). Effect of crop maturity and plant density. J. Industrial Crops Prod. 25: 282-287.

Corbineau F., Picard M.A., Bonnet A., Côme D., 1995. Effects of production factors on germination responses of carrot seeds to temperature and oxygen. Seed Sci. Res. 3: 129-135.

George R.A.T., 1985. Vegetable Seed Production. Longan Group, Ltd.

Gray D., 1979. The germination response to temperature of carrot seeds from different umbels and time of harvest of the seed crop. Seed Sci. Technol. 7: 169-178.

HoŁubowicz R., Ratajczak K., Kryślak K., 1992. Internal seed structure of selected vegetable species. Acta Bot. Hung. 37: 267-277.

IsTA, 1999. International rules for seed testing. Seed Sci. Technol. 27, Supp. Rules.

Kawecka M., Dyduch J., 2006. Ocena cech biometrycznych i potencjału plonotwórczego roślin kilku odmian kopru ogrodowego (Anethum graveolens L.) w uprawie polowej na zbiór pęczkowy. Ocena potencjału plonotwórczego. Acta Agrophysica 8: 611-617.

Kaufman W., Pölitz J., 1990. Wirkung von Saatgutbehandlung und Bestandsdichte auf Entwicklung und Ertrag von Dill (Anethum graveolens L.). Arch. Gartenbau, Berlin 38: 121-129.

Kaur G.J., Arora D.S., 2010. Bioactive potential of Anethum graveolens, Foeniculum vulgare and Trachyspermum anni belonging to the family Umbellifeare - current status. J. Med. Plants Res. 412: 87-94.

Kelly A.F., George R.A.T., 1998. Umbelliferae: Vegetable Crops. In: "Encyclopaedia of Seed Production of World Crops", John Viley \& Sons, Chichester, Toronto: 364-270.

Komorowska J., SoKoŁowska A., 1990. Zależność między zdolnością kiełkowania a wschodami warzyw w polu. VII. Koper. Biul. Warz. 35: 75-85.

Korohoda J., 1974. Koper. In: "Produkcja nasion roślin warzywnych", PWRiL, Warszawa: 270.

LiTYŃSKi M., 1977. Biologiczne podstawy nasiennictwa. PWN, Warszawa.

McDonald M.B., Copeland L.O., 1997. Seed Production. Principles and Practices. Chapman \& Hall, New York, Paris, Washington.

Munammad A., Anjum M.A., 2001. Effect of Root size, plant sparing and umbel order on the quality of Asiatic carrot (Daucus carota L.). Indian J. Agric. Biology 3: 239-242.

Panayotov N., 2010. Heterogeneity of carrot seeds depending on their position on the mother plant. Folia Hort. 22(1): 25-30.

Pereira R.S., Nascimento W.M., Vieira J.V., 2008. Carrot seed germination and vigor in response 
to temperature and umbel orders. Sci. Agric. 65: 145-150.

Randhawa G.S., Singh A., Mahey R.K., 1987. Optimizing agronomic requirements for seed yield and quality of dill (Anethum graveolens L.) oil. Acta Hort. 208: 61-72.

Satyaveer S., Nehra B.K., Malik Y.S., Singh S., 1994. Carrot seed yield and quality as influenced by different order umbels under varying nitrogen, plant density and geometry. Crop Res. Hisar 3: 543-548.

Shantha N., Pandita V.K., Sharma D., Nagarajan S., 1999. Effect of sowing time and umbel order on emergence characteristics of Asiatic carrot Daucus carota L. Seed Res. 2: 125-130.

SokoŁowska A., Szafirowska A., Janas R., KŁosowski S., Woyke H., 1994. Współzależność między wybranymi cechami nasion a wschodami kopru (Anethum graveolens L.) w polu. Biul. IHAR 192: 135-141.

SZAFIROWSKA A.I., 1994. The correlation between mother plant arrchitecture, seed quality and field emergence of carrot. Acta Hort. 354: 93-97.

Szopińska D., Bralewski T.W., 2006. Dill (Anethum graveolens L.) seed stalk architecture and seeds infestation with fungi. Not. Bot. Hort. Agrobot. Cluj 34: 75-78.

Woyke H., 1989. Problemy jakości nasion warzyw w świetle badań Instytutu Warzywnictwa. Biul. Warz. Suppl.: 23-28.

WOYke H., ŁAZĘCKA M., 1993. Wpływ architektury nasiennika na jakość nasion kopru. Biul. Warz. 40: 71-78.

Woyke H., ŁAZĘCKA M., 1994. Wpływ fazy dojrzałości na jakość nasion kopru (Anethum graveolens L.). Biul. Warz. 41: 5-15.

\section{WPŁYW POŁOŻENIA BALDACHU NA KOPRZE (ANETHUM GRAVEOLENS L.) ROSNACCYM W ŁANIE NA POLU NA WYBRANE CECHY PĘDU NASIENNEGO}

Streszczenie: W latach 2002-2004 przeprowadzono badania nad wpływem położenia baldachu na roślinie kopru (Anethum graveolens L.) odmiany 'Amat' rosnącej w łanie, na wybrane cechy morfologiczne pędu nasiennego. Nasiona handlowe wysiano na małym polu produkcyjnym i uprawiano $\mathrm{z}$ przeznaczeniem na zbiór nasion. Z łanu kopru wybrano losowo trzysta roślin, na których oceniono następujące cechy morfologiczne pędu nasiennego związane $\mathrm{z}$ jego architekturą: długość pędu nasiennego, liczba pędów z baldachami pierwszego, drugiego i trzeciego rzędu, długość pędów z baldachem pierwszego rzędu jak również średnice baldachu głównego i pierwszego rzędu. Ponadto, oceniono plon nasion $\mathrm{z}$ rośliny, mase 1000 nasion, zdolność kiełkowania nasion, długość i szerokość nasion oraz długość zarodka i bielma w nasieniu. Dodatkowo, w trakcie badań, baldachy główny i pierwszego rzędu podzielono na 3 części: zewnętrzną, środkową i wewnętrzną i oceniono oddzielnie pochodzące $\mathrm{z}$ nich nasiona. Położenie baldachu na pędzie nasiennym nie wpłynęło na liczbę odgałęzień $\mathrm{z}$ baldachami pierwszego, drugiego i trzeciego rzędu i cecha ta nie wpłynęła na architekturę pędu nasiennego. Nie wykazano istotnej różnicy w wysokości położenia baldachów głównego i pierwszego rzędu na roślinach kopru rosnących w łanie na polu. Położenie baldachów głównego i pierwszego rzędu na roślinie rosnącej w łanie nie wpłynęło na ich średnicę. Wraz z obniżeniem się rzędowości baldachu zmniejszył się plon nasion $\mathrm{z}$ baldachu $\mathrm{i}$ ich zdolność kiełkowania. Najlepsze nasiona, ze względu na masę 1000 nasion, pochodziły z zewnętrznej części baldachu głównego. Zróżnicowane położenie nasion w poszczególnych częściach baldachu głównego nie wpłynęło na ich długość i szerokość jak również na długość zarodka i bielma w nasionach. Zarodki $\mathrm{w}$ nasionach dojrzewających w wewnętrznej części baldachu pierwszego rzędu były krótsze niż zarodki z pozostałych dwóch części tego baldachu.

Received November 18, 2010; accepted December 14, 2011 